\title{
The Grass Roots of English History: Local Societies before the Industrial Revolution
}

Review Number: 2054

Publish date: Thursday, 26 January, 2017

Author: David Hey

ISBN: 9781474262514

Date of Publication: 2016

Price: $£ 65.00$

Pages: 240pp.

Publisher: Bloomsbury Academic

Publisher url: http://www.bloomsbury.com/uk/the-grass-roots-of-english-history-9781474262514/

Place of Publication: London

Reviewer: Richard Hoyle

I knew David Hey for 30 years, and it is with great sadness that I offer this review of his last and posthumous book. I recall well how I first met him. It was Easter 1985 and I was on my way to the British Agricultural History Society conference to give a paper. I hadn't been to that conference before, nor had I ever given a paper to a conference (as opposed to a seminar). I found myself on the same train to Harrogate as David, and he, perhaps sensing that this distracted young man (trying to anticipate all the possible questions he might receive) was going in the same direction, asked who I was and applied the appropriate balm. It was a characteristically generous gesture.

And so he became part my professional life. Although he had been a doctoral student of Alan Everitt's, Joan Thirsk had examined his thesis on Richard Gough and Myddle (Shropshire) and so we were both part of that rather irregular group known to its members as the 'Friends of Joan'. We moved in the same circles in the British Agricultural History Society (which he served in many capacities and latterly as President). I published him several times in Agricultural History Review. We met at conferences (the last occasion a memorial meeting for Joan Thirsk just two years ago: he had also spoken at her 80th-birthday conference, which I organised). I see that the last time I emailed him I included him in a round robin saying that I had been appointed Director of VCH. 'I don't envy you in that particular role', he replied 'but I am delighted that you have the title of Professor of Local and Regional History as I am sure that you will bring lustre to my field of interest'. I expected to see him at the Agricultural History Society conference last Easter which was held in what might reasonably be called 'Hey country', at Wortley Hall near Sheffield, when we would doubtless have discussed how the lustre had rubbed off. But illness claimed him first, and the excursion he was to have led turned into a session where I and others reminisced about a valued colleague.

Knowing David helps explain much about this book, and conversely the well-attuned reader might learn much about him from it. He was a Yorkshireman, from the Pennines around Penistone. He never lost (and perhaps even cultivated) his accent. He came into the academic world by a route which is now largely closed, that of school teaching and a part-time doctorate. He held a research fellowship at Leicester in the glory days of the Department of English Local History, but then made a sideways move to the extra-mural department at Sheffield. I once asked him why: his response was that teaching adults was much more 
rewarding than teaching undergraduates but one felt that his real reason was that the job offered him a ticket back to Yorkshire and to his home pastures. And so he became Mr Sheffield History and wrote extensively about the history of the 'South Riding' and latterly Derbyshire too. Some of the publications were much as one might expect from a regional historian - the histories of Sheffield, Yorkshire and Derbyshire, for example. Much was genuinely pioneering, such as his work on dual economies or the routes over the uplands, work which came from the pen of a man who had a deep understanding of both the historical sources and the landscape, and ready access to both.(1) As a local historian he spanned both the urban and the rural, but came especially to write about the moors of South Yorkshire and the Dark Peak. As he once admitted to me, he did not hesitate to trespass when the need arose.(2) This was a clue to a side that none of us knew much about, his prominence as a rambler and his Presidency of the South Yorkshire and NE Derbyshire Ramblers Association.

If much of David's work was focussed on South Yorkshire, in the latter part of his career and in his retirement he expanded into writing more generally about local history (he invited me to contribute to the Oxford Companion to Local and Family History in 1996). He had a long-standing interest in surnames and their distribution. Perhaps this was one of things he owed to Leicester and Hoskins. Surname studies, but concentrating on their origins, was a Leicester speciality. Hoskins wrote a chapter on surnames as a tool for local historians in the third edition of his Local History in England (1984, where David's contribution is especially warmly acknowledged). David developed a particular interest in surnames and their distribution and perhaps more than anyone else advocated surnames as an historical source. John Beckett recalls that he started with telephone directories: the online censuses were a boon to him.

The present book is a summation of David's approach. What it amounts to is a statement of a distinctive approach to history. It is not economic history. Nor is it history as it is taught in any undergraduate syllabus known to me (which is a statement of regret as well as fact). It is a statement of what pre-modern (both medieval and early modern) local history ought - or perhaps might - be. So we start with a chapter called 'The countries of England'. 'Country' is a word that interested David, indeed, it is indeed fundamental to his approach. It denotes the area that people knew from their own experience and therefore a limited and bounded district. This leads into a discussion of the distinctive surnames of a country. The fact that surnames are strongly localised define the country. But then this chapter switches into an account of London and the movement of people to and from London, whether as migrants or as carriers and drovers. There is much in this chapter that underpins the book, and some of its themes reappear at the very end.

Then we turn to the people of England - a brisk canter through a thousand and more years of history, of migration and state building, but again with an interest in the way in which migration introduced new surnames. The following chapters are more orthodox: towns and cities in chapter three, a landscape-based approach to the countryside in chapter four, a discussion of agriculture in chapter five; castles and the houses of the aristocracy in chapter six; parish churches and chapels in chapter seven and timber-framed houses in chapter eight. These have some features in common. They are well-informed and bang up-to date, and can usefully be consulted by those looking for quick accounts of the state of our knowledge and understanding. They draw heavily on the author's knowledge of his 'country' so there is a strong vein of examples taken from south Yorkshire and the north Midlands. Occasionally the authorial voice comes over strongly: when he says that Elizabethan prodigy houses 'can be regarded as either energetic and imaginative expressions of the age or as vulgar displays of new found power and wealth' (p. 124), one can easily guess where David stood on the matter. But these chapters are also heavily physical in their preoccupations. They are about the land, and the buildings which stood on it. It is not that people are absent, but that there are no people in the buildings. The account of monasteries is about the buildings rather than monastic practice and the churches are without religion. The placing of altars, the presence (or not) of altar rails, all matters which generated heat in the 16th and 17th centuries, are passed over. The laity have no spiritual life nor is the church considered as a communal centre. There is no discussion of the aristocratic household as employer or consumer. There are other omissions. There is a missed opportunity to discuss and illustrate the work of Roberts and Wrathmell on settlement and to pose the question of what different types of settlement imply for the lives of the people who lived in them. (John Aubrey gets a quick citation.) I missed an account of 
commons and commoning in chapter four: a passing mention in the context of enclosure, yes, but a sustained discussion is absent. There is no discussion of the furnishings of houses, or the standard of living. David did his time on the inventories, but does not draw on them here.

Now I would be the first to admit that publishers impose word lengths and that an author bringing together a book like this has to prioritise and, from time to time, omit areas for discussion. But with this in mind, let us turn to chapter nine, 'Population, family life and society' which is both the last chapter and the conclusion as there is nothing further to draw the volume together. This begins with an account of 'population growth, loss and recovery'. This section gets slightly lost in accounts of disease and famine. We then turn to 'English families' and David outlines the characteristics of the household before turning to 'The "deserving poor" and vagabonds'. I think that the deserving poor and the way they were treated by their communities deserved a more expansive treatment. But it is then on to a discussion of the 'core families of local communities', a section to which I will return, and then a little over a page on overseas migration. And then four pages on 'speech and literacy'.

This may well give a sense of the compression going on here, but there are two sections which seem very revealing of how David saw local society. He is interested in those families which did not move, but stayed rooted in the communities over long periods.(3) We might call this the Starkadder approach to history: 'There have always been Starkadders at Cold Comfort. 'Tes impossible for any on us to dream o' leavin' here'.(4) The reality of families who remained at the same farm generation after generation - be it Cold Comfort Farm or elsewhere - or in the same village is not to be doubted. It is a phenomenon that Angus Winchester has described for the Lake District and it is certainly found in the Yorkshire Dales. Henry French and I found a few instances of the phenomenon in Earls Colne, although not all the long-term landholding families were resident in the village. I would imagine that most local historians could probably offer instances of successive generations remaining in the same place. This then relates back to the discussion of surnames and their localisation, and if there is any doubt of the connection in David's mind, we have a picture of Crowder House in South Yorkshire. It bears the caption 'The Wilkinson family farmed here through direct inheritance, from 1402-1859'.(5) And figure two shows how Wilkinson is a distinctively northern name. But when we turn to the discussion of dialect, David tells us that

Language was a sure indicator of the identity of local neighbourhoods, or 'countries', centred on the nearest market towns. The tone and diction of the local accents were distinctive even if the words looked the same in print (p. 189).

In fact dialect, surnames and 'countries' were all features of the same society.

The core groups of local families were the one who set the patterns to which incomers eventually conformed (p. 189).

The distinctive characters of the numerous 'countries' of England were formed not only by local speech, customs, beliefs and attitudes, but by their styles of vernacular architecture, the nature of their crafts and their farming systems (p. 190).

Before the great changes of the modern era, the English nation was composed of hundreds of local societies that had contacts beyond their parish boundaries as far as the nearest market towns, but which remained mostly unaware of the people in distant parts of the realm.

And these are the closing words of the book.

Here David is taking a fairly familiar position on the character of village society and applying it to the preindustrial period. It is well evidenced by 19th- and early 20th-century observers (although normally they described how the village had been to explain how it had changed). For instance, here is G. T. Garratt 
writing in 1928.

Thirty years ago the average villager's life was bounded in on every side. Work, sex, drink, parentage, quarrelling and scandal made up nearly all their interests. A few found consolation in religion and some found relaxation in cricket or going after rabbits with a dog. Few of the Oxfordshire villagers had seen the sea, most of those where I lived had never travelled by train and many lived and died without going five miles from their home. ... [M] any villagers, even in a small hamlet, hardly saw each other from year's end to year's end.(6)

Yet David was far too good a historian to maintain this view absolutely and offers plenty of contradictory evidence. He knows, and describes, migration, even migration abroad, and acknowledges it to have been a familiar part of society. The drift to London is given appropriate weight. He tells us that Richard Gough 'had numerous contacts with people beyond his parish boundary and was aware of national events and issues' (p. 185).

It would be pleasant to argue this out with David, over a pint (or several) at an Agricultural History Society conference but the opportunity has passed. So all I can do is say that I find it hard to accept the argument David seems to be making for an intense localism and lean much more towards the countervailing evidence which he himself offers.

Within England there was a constant movement of people, Professor Rollison's 'traffic' (7): for every man who never travelled more than five miles in his life, another was taking goods round the countryside, driving animals long distances, carrying rents to London. Parish officeholders were going to the county town on a whole variety of bits and bobs of parish business. People moved around for seasonal work, and even the poor could be mobile (although the authorities disliked both the idea and the practice). Wrigley showed many years ago how London sucked young people out of rural England, especially the south, in the 17th century and later: all big towns had a similar effect on their surrounding districts. Young men followed welltrodden paths from grammar schools to Oxford and Cambridge and college livings. Men were also taken well away from their natal parish by military service, whether on land or sea. Of course, many never came back, but others doubtless spent their dotage in the village alehouse telling of the sights they had seen in France, the Mediterranean, even the Americas or India.

Moreover, the town could come to the countryside. As I have shown in a piece I recently published on Peter Walkden, newspapers could be obtained on loan from alehouses in rural Lancashire in the second quarter of the 18th century.(18) Even if farm labourers had little political consciousness, the farmers were well aware of national, political developments.

Of course, one might argue that whilst there were people in the village and countryside who were genuinely men of the world, there were others who were indeed confined to the bounds of the village both in their travels and in their knowledge of the world. It might plausibly be argued that it was richer individuals who had the education and leisure to immerse themselves in religion or politics, who might be drawn on for parish offices and jury service and might have interests - legal, economic - which took them to county towns or even London. And yet it would be wrong to argue that all labouring jobs were as rooted in locality as Garratt describes. Seasonal migratory labour was common enough and even if Hodge was rooted in the village of his birth and marriage, he worked alongside men and even women who had travelled long distances.

There were good reasons for people with property to stay in the village of their fathers. The possession of land might be a trust given by one's ancestors for one's children and their children. But it was inevitable that the family farm could provide for those children only so far, and then they had to leave, and doubtless expected to leave, and communities provided the education to enable them to leave. Of course, the implication is that whilst the Starkadders remained at Cold Comfort, in every generation the younger 
Starkadders were sent out throughout England - if not the world - to make their living, the bearers of a rare and recognisable name. A Starkadder here, another there, make no impression on distribution maps drawn from the 1881 census.

And one might argue that villagers were the residue left when those who had some get up and go had got up and gone. Or perhaps the ones that went were those who secured some education and basic literacy and numeracy which allowed them to make their way in the world. But those villagers who themselves never left must increasingly have had brothers and sisters who worked in the Satanic mills of the larger towns, brothers who had taken the king's shilling of one sort or another and family who were voluntary (or even involuntary) migrants to Americas or the antipodes.

So my suggestion is that David's book is underpinned by a very particular reading of rural history. It is not one that I can fully accept. It is a highly personal vision, perhaps coloured by the fact that David was a Yorkshireman who did return home (even if he lived in Dronfield), and spent his career and retirement immersed in the history of his 'country'. It reads differently for a Yorkshireman living, to his own occasional bewilderment, south of the Thames, who left his 'country' behind long ago.

And yet if I can't go the full distance with David, this remains a highly individual and admirable book. David used the freedoms given him by his post in Sheffield to develop his own syllabuses, teach according to his own priorities and research themes which interested both himself and his students. He was lucky to have had that freedom. Equally Sheffield and the south of the West Riding were fortunate to have had a historian of such quality and insight working on its history. And many of us were blessed by knowing him. The Grassroots of English History is a very personal vision of what local history might be, a rejection of most school and undergraduate history, the outcome of a lifetime's reading, thinking, teaching and writing local history. As an alternative reading of our history, it deserves our attention, and one only regrets that David is no longer with us to debate its premises and conclusions.

\section{Notes}

1. The Rural Metalworkers of the Sheffield Region: a Study of Rural Industry before the Industrial Revolution (Leicester, 1972); Packmen, Carriers and Packhorse Roads: Trade and Communication in North Derbyshire and South Yorkshire (Leicester, 1980).Back to (1)

2. The grouse moors of the Peak District', in Landscape history after Hoskins, III, Post medieval landscapes (Macclesfield, 2007), ed. P. S. Barnwell and Marilyn Palmer, pp. 68-79; A History of the Peak District Moors (Barnsley, 2014).Back to (2)

3. David discussed the idea in earlier publications: one of his more popular offerings of a decade ago included a chapter entitled "Core families and "country"' where much of the argument here can be found in embryo. David Hey, Journeys in Family History (Kew, 2004), pp. 173-7.Back to (3)

4. Stella Gibbons, Cold Comfort Farm (London, 1932, Penguin Classics edn, 2006), p. 56.Back to (4)

5. The same illustration also appears in Journeys in Family History. Back to (5)

6. G. T. Garratt, Hundred Acre Farm (London, 1928), p. 90.Back to (6)

7. David Rollison, A Commonwealth of the People. Popular politics and England's Long Social Revolution, 1066-1649 (Cambridge, 2010), pp. 69-73 and other references.Back to (7)

8. Peter Walkden and the world of goods', in Farmers, Customers, Innovators. The World of Joan Thirsk , ed. C. Dyer and R. Jones (Hatfield, 2016), pp. 139-56. Back to (8)

Source URL:https://reviews.history.ac.uk/review/2054

Links

[1] https://reviews.history.ac.uk/item/183775 